\title{
Front Matter: Volume 12159
}

, "Front Matter: Volume 12159," Proc. SPIE 12159, SPIE Advanced Biophotonics Conference (SPIE ABC 2021), 1215901 (12 January 2022); doi: 10.1117/12.2628261

SPIE Event: SPIE Advanced Biophotonics Conference (SPIE ABC 2021), 2021, SPIE. Busan, Republic of Korea 


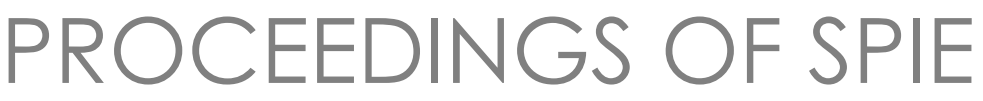

\title{
SPIE Advanced Biophotonics Conference (SPIE ABC 2021)
}

\author{
Euiheon Chung \\ Ki-Hun Jeong \\ Chulmin Joo \\ Woonggyu Jung \\ Hyun-Wook Kang \\ Chang-Seok Kim \\ Chulhong Kim \\ Pilhan Kim \\ Hongki Yoo \\ Editors
}

4-6 November 2021

Busan, Republic of Korea

Hosted by

Optical Society of Korea (OSK)

Published by

SPIE 
The papers in this volume were part of the technical conference cited on the cover and title page. Papers were selected and subject to review by the editors and conference program committee. Some conference presentations may not be available for publication. Additional papers and presentation recordings may be available online in the SPIE Digital Library at SPIEDigitalLibrary.org.

The papers reflect the work and thoughts of the authors and are published herein as submitted. The publisher is not responsible for the validity of the information or for any outcomes resulting from reliance thereon.

Please use the following format to cite material from these proceedings:

Author(s), "Title of Paper," in SPIE Advanced Biophotonics Conference (SPIE ABC 2021), edited by Euiheon Chung, Ki-Hun Jeong, Chulmin Joo, Woonggyu Jung, Hyun-Wook Kang, Chang-Seok Kim, Chulhong Kim, Pilhan Kim, Hongki Yoo, Proc. of SPIE 12159, Seven-digit Article CID Number (DD/MM/YYYY); (DOI URL).

ISSN: 0277-786X

ISSN: 1996-756X (electronic)

ISBN: 9781510651944

ISBN: 9781510651951 (electronic)

Published by

SPIE

P.O. Box 10, Bellingham, Washington 98227-0010 USA

Telephone +1 3606763290 (Pacific Time)

SPIE.org

Copyright (C) 2021 Society of Photo-Optical Instrumentation Engineers (SPIE).

Copying of material in this book for internal or personal use, or for the internal or personal use of specific clients, beyond the fair use provisions granted by the U.S. Copyright Law is authorized by SPIE subject to payment of fees. To obtain permission to use and share articles in this volume, visit Copyright Clearance Center at copyright.com. Other copying for republication, resale, advertising or promotion, or any form of systematic or multiple reproduction of any material in this book is prohibited except with permission in writing from the publisher.

Printed in the United States of America by Curran Associates, Inc., under license from SPIE.

Publication of record for individual papers is online in the SPIE Digital Library.

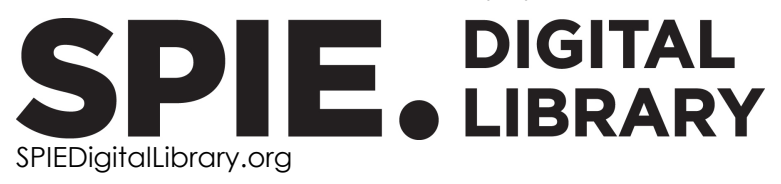

Paper Numbering: A unique citation identifier (CID) number is assigned to each article in the Proceedings of SPIE at the time of publication. Utilization of CIDs allows articles to be fully citable as soon as they are published online, and connects the same identifier to all online and print versions of the publication. SPIE uses a seven-digit CID article numbering system structured as follows:

- The first five digits correspond to the SPIE volume number.

- The last two digits indicate publication order within the volume using a Base 36 numbering system employing both numerals and letters. These two-number sets start with 00, 01, 02, 03, 04, $05,06,07,08,09,0 A, 0 B \ldots$.. OZ, followed by 10-1Z, 20-2Z, etc. The CID Number appears on each page of the manuscript. 


\section{Contents}

SPIE ADVANCED BIOPHOTONICS CONFERENCE (SPIE ABC 2021)

$1215902 \quad$ Noise reduction technique for fluorescence imaging in multifocal multiphoton microscopy [12159-3]

1215903 2-D transition metal dichalcogenides assisted SPR biosensor for rapid detection of urine glucose [12159-4]

$1215904 \quad$ Novel endoscopic laser treatment of common bile duct stenosis using balloon catheterintegrated diffusing applicator (BCDA) [12159-6]

1215905 High-throughput screening platform for quantitative phenotype analysis of Xenopus laevis with deep learning [12159-8]

1215906 Compact hyperspectral camera using angle-sensitive plasmonic structures [12159-9]

1215907 Integrated photoacoustic and ultrasonic endoscopy mini-probe for use in the instrument channel of a clinical video endoscope [12159-11]

1215908 Marker-free protein study by amplified light scattering [12159-12]

1215909 Development of a portable ophthalmic OCT device and measurement of its performance [12159-13]

12159 OA Photobiomodulation-based skin-care effect of organic light-emitting diodes [12159-14]

$12159 \mathrm{OB} \quad$ Integrated photoacoustic and ultrasonic endoscopy as a new tool for the early diagnosis of malignant biliary stricture [12159-15]

12159 OC Opto-chemical disinfection of bacterial pathogens in mature biofilms grown in flexible endoscope [12159-17]

12159 OD Phlorotannin-combined photobiomodulation for prevention of tracheal stomal stenosis posttracheostomy: in-vitro and in-vivo evaluations [12159-18]

$12159 \mathrm{OE}$ Optical and thermal effects of air trap on cylindrical laser treatment of tubular stenosis [12159-19]

12159 OF Stimulatory effects of laser wavelengths on proliferation and angiogenesis of colon cancer: in-vitro and in-vivo evaluations [12159-20]

12159 OG Deep-learning-based characterization of laser-induced scar tissue [12159-22]

$12159 \mathrm{OH} \quad$ Picosecond laser irradiation by using micro-lens arrays and diffractive optical elements on different skin types [12159-23] 
Proc. of SPIE Vol. 12159 1215901-4 Downloaded From: https://www.spiedigitallibrary.org/conference-proceedings-of-spie on 25 Apr 2023
Terms of Use: https://www.spiedigitallibrary.org/terms-of-use 